\title{
The Idiosyncrasy of Israeli Philanthropy-Government Interaction
}

\author{
Uzi Sasson \\ Beit Berl College, Kfar Saba, Israel \\ Email: uzi.sasson@gmail.com
}

Received 20 February 2015; accepted 7 March 2015; published 11 March 2015

Copyright (C) 2015 by author and OALib.

This work is licensed under the Creative Commons Attribution International License (CC BY). http://creativecommons.org/licenses/by/4.0/

C) (i) Open Access

\section{Abstract}

The purpose of the study is to evaluate two different systems, in the relations between the government and philanthropy. While the one is controlling in regulation, the other is establishing a committee that will standardize philanthropy activities in Israel. I use the Israeli government actions vs. philanthropic activities as a case study to demonstrate my assumptions and conclusions. As far as the government-philanthropy relationship is concerned, Israel is a unique case. In this paper, I will expand on the ramifications of the political system and explain how it influences the government and philanthropy relationship. I will explain the political system in Israel. I will define and describe the military elite and its power in the government and in the civil society. I will then sort out the efforts of the government to preserve its power against the opposition, and further explain the implications on the operation of the foundations in Israel. In summary, I will suggest a possible platform for foundations to actively and positively invest their resources under the current political landscape.

\section{Keywords}

Philanthropy, Regulation, Government, Third-Sector

Subject Areas: Business Ethics and Corporate Social Responsibility, Politics

\section{Introduction}

It is reasonable to assume that for many governments foundations are a benefit to the public. The rationale behind this assumption is that as a result of the activity foundations involved in, the government's stability increases. The public satisfaction, with the advancement of social aspects of education, health, welfare, and a general improvement in the quality of life, colors the government in bright light. Unfortunately, this positive correlation is not the case as far as the Israeli government is concerned and how it perceives philanthropy. Specifically, the government's attempts to restrict philanthropic activities by correcting the Company Law and the Internal 
Revenue Service Command (2011) expose a very unhealthy relationship between the Israeli government and philanthropists in Israel. In this paper I will explain and exemplify the problematic political system which produces the distrustful effect it has on philanthropic activities.

Israel is a unique case as far as the government-philanthropy relationship is concerned, for two main reasons: the method of government in Israel and the power of the military elite in the country. Israel is a multi-party coalitional democracy and the formation of a coalitional government involves power relations between the parties of the coalition. These are often characterized by a "give and take" approach which basically means that in return for participating in the coalition, the chair of the party, which receives the highest number of seats, compensates the sector represented by the small party. This compensation often results in coalitions, and ultimately governments, which allocate funds to small sectors due to coalitional agreements. In this paper, I will expand on the ramifications of the political system and explain how it influences the government and philanthropy relationship.

Because governments in Israel depend on coalitions, they are often unstable. The opposition gets into the picture by posing an alternative to the government (Almond and Verba, 1963 [1]; Koren and Shapira, 1997 [2]). To weaken its power, the government decreases the allocation of resources to oppositional parliamentary activities (Dahl, 1961 [3]; Koren and Shapira, 1997 [2]). Since the opposition has less governmental support and less control on public budget, it turns to private foundations and asks for their support. The endowments made to the opposition may influence the government stability, for they pose a potential threat to the government (Koren and Shapira, 1997 [2]).

Furthermore, the biggest group in the Israeli politics is the military group as many senior officers who retire take on a second career in politics. This increases the group's power and its ability to influence governmental decision-making process. However, the military cohort is not only well represented in Israeli politics, but it has power in the public as well, since those who do not go to politics when retired serve in key positions in Israeli economy. Hence, the government increases the budget to this sector on the expense of social values and priorities.

In this paper I will further expand on the above thesis. I will start with explaining the political system in Israel. I will define and describe the military elite and its power in the government and in the civil society. I will then sort out the efforts of the government to preserve its power against the opposition, and further explain the implications on the operation of the foundations in Israel. In summary, I will suggest a possible platform for foundations to actively and positively invest their resources under the current political landscape.

\section{The Method of Government in Israel}

\subsection{Coalitional Agreements Prioritizes Financial Government Agenda}

Israel is a representative democracy; and as in other democracies, once in four years, citizens determine who will be a member of the ruling representative body in the country. The leading principle is that that only a very small group of people becomes the voice of the mass. In Israel, this mall group, also known as the Knesset, is composed of 120 representatives who represent around 50 parties. Each party that wishes to have its voice heard in the House of Representatives has to have at least 2 representatives in the Knesset, which of course commensurate with the number of the people who voted for that party. Parties that do not accumulate the approved cap of votes will not have any representatives in the Knesset (Harman, 1990 [4]; Koren and Shapira, 1997 [2]).

As in other representative democratic societies, the Israeli Knesset has to support the establishment of a smaller executive ruling body - the Israeli government. However, because Israel is also defined as a coalitional democracy, the process through which Israeli governments are formed is critical to the priorities and preferences that these governments will adopt. Coalitional democracy, in other words, means that a number of parties make an agreement to build a coalition that will ultimately enable them to execute national-level decisions and fund these decisions with public money under The Budgetary Law (Harman, 1990; Koren and Shapira, 1997 [2]).

The process of forming a coalition and maintaining it is extremely manipulative. It reflects the conflicting priorities, values and opinions of different parties that can be rarely bridged or compromised. However, because being in the government means having power, parties get into coalitional agreements even though priorities and preferences do not always agree (Harman, 1990 [4]; Koren and Shapira, 1997 [2]). For that reason, many times coalitions fall apart, what cause the Israeli political system to be unstable. The history of governments in Israel demonstrates that governments often last for a shorter time then the 4 years they elected for initially. It is important to mention in this context that the multi-parties democratic system in Israel is different than a two parties 
system, which eliminates the need to form a coalition and employ manipulative strategies to create a government whose parties have common basis (Koren and Shapira, 1997 [2]; Harman, 1990 [4]).

As in every western democratic country, the government is committed to the rule of law. However, in Israel the decisions of the government are very much determined by the electoral system in Israel, according to which, citizens who are eligible to vote determine which party's delegations will number more chairs in the Knesset. The number of mandates given to each party is proportional to the number of votes it receives in the elections (Koren and Shapira, 1997) [2]. For example, a party which receives $10 \%$ votes will receive $10 \%$ of Knesset mandates and its members will man $10 \%$ of the Knesset's 120 positions. Because the qualifying threshold that enables a party to enter the parliament is $2 \%$, representatives from many small political parties form the Israeli Knesset. The chair of the party who won the highest number of votes has to form a government by cooperating with other parties. Only if he is able to create a coalition of parties whose total number of mandates exceeds 61 will he be the Prime Minister.

The 18th elections to the Knesset, on 10 February 2009, are a good example that illustrates to what extent coalitional agreements determine the structure of the government. In that election system, the a second biggest party, the Lickud, which could compose a coalition even though the biggest party, Kadima, had more mandates At the 18 th elections Kadima won $22.47 \%$ of the votes and received 28 mandates, out of 120 , in the Knesstt, while the Lickud received only $21.61 \%$ of the votes and received 27 mandates. The other big parties who won their chairs in the Knesset were Israel Beitynu with 15 mandates and Ha'avoda with 13 mandates. The religious parties won 23 mandates altogether, and the 4 "Arab" parties won 14 mandates together. A total of 12 parties occupy 120 chairs in the Israeli House of Representatives - the Knesset.

The 32nd coalition composition process was a tricky one, since the Likod - the second biggest party was ordered by the Israeli president-Shimon Peres to start and negotiate the composition of the 32nd government. President Peres concluded that Mr. Netanyahu, whose party had only 27 mandates, can build a coalition, and not Ms. Livny, whose party gained 28 mandates, because 65 members of the Knesset signed a document declaring support for Mr. Netanyahu while Ms. Liveny could collect only 28 signatures (her party members' signatures). Eventually, the 32nd government, led by Prime-Minister Netanyahu, was composed of 30 ministers and 9 deputies, and became the largest government ever served in history of Israel.

Another example is the 2009 elections. Shas, an ultra-orthodox religious political party in Israel, won 11 mandates, and in return for joining Benjamin Netanyahu's coalition, it was paid four cabinet posts. The implication of this was that the leaders of this party were positioned in high-profile governmental offices that directly influence the agenda of the government. In this specific case, the meaning was that major funds were given to the religious sector.

As seen above, unfortunately, many times, coalitional agreements influence the structure of governments and dictate how resources are going to be allocated in Israel. When a party is badly needed to reach a coalition of 61 mandates, it will be given more ministerial portfolios than it deserves, and the ministers who chair the main offices in the government will naturally promote the interests of the sector which voted for them.

Clearly, the role of the government is mainly to prioritize public needs and resources. The meaning is that by law the government can allocate, for the use of the different ministerial offices, a total amount collected from the Israeli citizens. To exemplify, the 32 nd government is authorized to spend approximately 270 billion NIS in the year of 2011 (according to the Israeli Budget Law 2011). This budget is allocated according to the power of the parties who negotiate their support in the coalition. The leader of the government has to make a 'payment' for the parties support in the government, in addition to maintaining the core support of his party members. This unstable process, therefore, threat the stability and the retention of the coalition.

\subsection{Opposition-Philanthropy Cooperation}

The opposition in Israel operates, by its definition, against the government's policy (Koren and Shapira, 1997 [2]; Shapiro, 1996 [5]; Dalton, 2008 [6]). Naturally, the government funds only activities that serve its own agenda. The government decides how big the opposition's budget is, and what role it will have in the parliament committees. The government can also ban, by law the amount of private endowments the opposition receives. By exercising the rule of law, the government can decrease to minimum the opposition's power (Koren and Shapira, $1997[2])$.

As a result, private funding, external to the public budget, is the adequate option that the opposition relies on. 
Foundations, such as The New Israel Fund, which has an opposite agenda to the one presented by the current Israeli government, are more likely to fund demonstrations against the government and organizations that advocate for topics that are prioritized higher in the opposition's view.

Thus, the opposition has less public resources than the government. Its choice of supporting external-parliament activities is with using private funds. The private funds, which support the opposition, hold opposite opinion from the government. Foundations, mainly from the USA, the UK and the EU, support opposition organizations that increase the instability of the government. These kind of support increase the suspicious way that the government perceives foundations in general. The respond of the government is restricting by regulation of all funding activities that goes to the opposition (Ha'aretz.co.il).

\subsection{The Case of the New Israeli Fund}

One of the examples for foundations' activities against the government is example of The New Israeli Fund. The New Israel Fund, which is a foundation centered mostly in the USA, is one of the foundations that funds political related projects in Israel. One such project is the social protest that took place in the summer of 2011 in Israel (Wikipedia.org) [7]. The Fund is registered as a 501 (C) (3) (nonprofit organization) since 1979 in Washington DC. (Guidestar.org) [8], and has centers in New York, Florida, Kansas, Maryland, Michigan, Mississippi, New Jersey, North Carolina, Pennsylvania, Virginia, West Virginia (NIF.org) [9]. In addition, it is registered as a nonprofit organization in Israel since 1992, and in Canada, UK and Swiss where it keeps local centers (Wikipedia.org) [7]. The New Israel Fund asks to dismantle the foundation registration as from 2012 in Israel. Nevertheless, its fiscal activities reported in 2009 the American IRS reflected contributions and grants of $\sim \$ 26.5 \mathrm{M}$ and $\sim \$ 34 \mathrm{M}$ in the year of 2008 (form 990, IRS 2009). It declares (NIF.org) [9] that it provided "more than $\$ 200$ Million to more than 800 cutting-edge organizations."

The New Israel Fund's vision is to "ensures complete equality so social and political rights to all its inhabitants irrespective of religion, race or sex" (NIF.org) [9]. Accordingly, The New Israel Fund actively supports, through funding and advocacy, hundreds of organizations that are considered by the foundation as leaders which promote equality and democracy in Israel. Some of these organizations have a "left-wing" orientation and actively produce reports, demonstration, advocacy, and other activities toward the promotion of their "left-wing" policy against the "right-wing" Israeli government. For instance, The New Israel Fund (NIF.org) [9] funds "Adalah which is a legal center for Arab minority rights in Israel" (NIF.org) [9]. It also supports "Breaking the Silence" that aims at "raising Public awareness about the moral dilemmas faced by soldiers serving in the occupied territories by collecting and publishing soldiers' testimonies, public events and advocacy" (NIF.org) [9]. An additional organization is SHATIL, which "promotes democracy, tolerance, and social justice in Israel", and work with organizations that "promote Jewish-Arab equality and coexistence, foster tolerance and pluralism, and encourage government accountability" (NIF.org) [9].

Although all institutions listed under The New Israel Fund (i.e., Adalah, Breaking the Silence, etc.) are legitimate in under the premises of a democratic regime, the activities of these organizations are considered provocative for a "right-wing" government. For instance, Adalah proposed, in 2007, a "democratic constitution" for Israel which should replace the Jewish fundamentalism of the state of Israel (Adalah.org) [10]. In 16 September 2009, the organization published "News Update", in which Adalah declares itself as a "Palestinian human rights organization" (Adalah.org) [10], and demands foreign governments to "re-evaluate their relationship with Israel" because Israel is accused by Adalah of committing "crimes against humanity" (Adalah.org) [10].

The image of "Breaking the Silence" in the Israeli society is of a "left wing" group which provokes the law and order of the Israeli police in the city of Hevron. "Breaking the Silence" promotes tours that are considered by police authorities dangerous to the police forces. Shai, a senior District Police official told Ynet on 18 June 2008 that "the activity of some leftist organizations in Hebron is more dangerous that which is being conducted by their right-wing counterparts". An article in Maariv newspaper [11] commented on 7 July 2009 that the soldiers' testimonies as published by the organization damage Israel defense forces and only portray the IDF as a violent force which aims to abuse the Palestinian society.

In addition, The New Israel Fund is known for its support for Goldstone report to the UN in September 2009. The report was a turning point in the relationship between foreign governments and the Israeli state. The report was considered to be a "diplomatic Tsunami" for Israel, while countries such as India and China supported the report. As opposed to that, The New Israel Fund identifies with the damage the report has caused (Maariv, 30 
January 2010) [11].

The New Israel Fund supported the demonstrations during spring of 2011. The upraising in Israel was recognized with the "middle class" expressing the disappointment from the economic hardship people suffer in Israel. The upraising was also known as the protest for social justice. Although the demonstrators demanded reasonable prices for housing, basic consumption products, and a discount for government services such as education and healthcare, the slogans called for a change of government.

The demonstrations involved hundreds of thousands of people who joined parades around major cities in Israel. The biggest demonstration took place in Tel-Aviv, while other demonstrations were in Haifa, Jerusalem, and Beer-Sheva. They mainly paraded during Saturday night, but during weekdays, the hardcore of the demonstrators were camping in major streets, sleeping in tents and having lectures and activities educating them how to shape their demands and what kind of solution to look for while in the camp.

In response to the demonstrations and the street activities, the government consulted Prof. Trachtenberg who advised for possible solutions to meet the demands. Prof. Trachtenberg advices were partly accepted. The main protestors' demand was to lower the high housing prices, and indeed, resulted from Prof. Trachtenberg's report, the government voted for a new housing plan. The plan includes expediting the building licensing, incentives for contractors who increase the number of student apartments and public transportations discounts for students who live far from the university campus, so they can seek cheaper housing in rural areas.

The Israeli government considers a number of "left-wing" foundations as the driving force of the demonstrations. The government accused the leaders of acting in the name of political change rather than economic reform. The demonstrations anonymously called for replacing the Prime Minister and the government he leads. Officials pointed out that Dafnie Leaf, who initiated the protest and led it, was a former New Israeli Fund's employer and therefore adopted the fund's leftist ideology. They further pointed out on the organizations that joined the protesters and supported the demonstrators (Shatil, Adam Teva ve'din, and others).

Nevertheless, The New Israel Fund was not alone in supporting the uprising of Israelis against the government. An additional philanthropist, such as Daniel Abraham, the founder of "Slim Fast" was one of the major economic engines who fueled the protest. Abraham explained (Nana.co.il) [12] that he decided to support the demonstrations because they call for stopping financial government support to the settlements and ultra-orthodox Jews, as part of the national fiscal budget. Mr. Abraham identifies himself as a left-wing political opinionated activist, who believes that finding a solution to the Israeli-Palestinian conflict will eventually result in economic relief. He funds the center for peace in the Middle-East, and donates to the left wing political rallies (News Channel 10) [13].

To sum up this subsection, these arguments and examples, written above, heighten our understanding in regards to philanthropy's motivations to contribute resources, fund the front line organizations, and get involved in political matters but also the support they give to opposite public opinion. The support of some foundations to the opposition is perceived as a threat on the government, and the consequences are regulations which block foundations activities of any kind in Israel.

\section{The Military Elite in Israel}

Elite is defined by Parry (2005) [14] and Nicholls (2008) [15] as a group of people who are powerful enough to act and set norms according to their own values and logic. It is an institution which selects its members carefully. Entering the elite is not easy as the power of the elite is in many ways reflected by its capacity to dictate the terms for entering its space. Fundamentally, conformity to standards of wealth, social background, educational attainment and commitment to the elite's interests and ideology are the basis premises of passing the gates of the group (Parry, 2005 [14]; Lukes, 2005 [16]; Etzioni-Halevy, 2000 [17]; Shapiro and Jacobs (2010) [18]; Shafir and Peled, 2002 [19]; Putman, 1976 [20]).

According to Lukes (2005) [16], Foucault, in Gordon (1980) [21], Etzioni-Halevy (2000) [17] and Parry (2005) [14] define former military personnel as elite. Furthermore, a key purpose of the elite is the ambition to strive for more power (Parry, 2005 [13]; Nicholls, 2008 [15]). Striving for power is a characteristic of individuals, organizations and elites too. This motivation is central in Israel which has strong military elite. This elite largely controls the decision-making in the parliament, the government and the civil society.

In Israel the high turnover of officers in the IDF expands the military elite. IDF's senior officers occupy positions in all sectors of the Israeli society and not only positions that are related to their previous experiences. These 
military past and present member have access to all sorts of power centers that control the country's most influential bodies. To illustrate, major-general Yeftach Ron-Tal, is the chairman of Israel Ports. Israel Port is responsible for $98 \%$ of the seaports of the country's import and export cargo (Israel Ports) [22]. Major-general Amiaz Sagis, who served the IDF for 32 years, was appointed in 1998 to the CEO of SuperSal groceries chain. Major-general Udi Adam became the general manager of the Negev Nuclear Research Center. Major-general Avital Rapaport occupies the Ministry of the Environment in Israel. Major-general Yaakov Even filled the position of the chairman of the National Coal Company. Major-general Gabi Ofir is the CEO of the Israel Airport Authority. Major-general Yizchak Chophie becomes the CEO of The Electricity Company.

Moreover, the army serves as a national academy for patriotic values. Since every 18 years old Israeli has to join the army forces, the society is being exposed to the military values (Etzioni-Halevy, 2000 [17]; Shapiro, 1984 [23]). Hence, when the argument of a threat on Israel is raised, people understand the meaning. Accordingly, the threat from Syria or a threat from the Palestinians is very vivid for people because they practice some military roles against these threats.

Ex-officers occupy key civil positions and gain more power. The IDF's senior officers retire from the military service, young enough to be able to serve as senior executives and leaders of civil key positions. In that way the government spreads the military elite's ideology in the civil forum. The military values reflect the government ideology. Thus, the government is using the military as mass opinion changing mechanism.

Because of the power of the military elite in Israel, the government is able increase the resources allocate to the army. In addition, the government gives administrative budgetary freedom to the military elite by separating the Ministry of Finance supervision from the national security budgetary priorities, and that increases power of the military elite and its benefits.

For instance, almost $50 \%$ of the ministers in the 32 nd government of Israel belong to the military elite. 16 ministers, out of 32 ministers have clear commitment to the military elite, while the rest 17 ministers belong to religious, academic, and other groups. The connection of the ministers to the military elite is very clear. The Prime Minister of Israel, Mr. Netanyahu, is the brother to Yoni Netanyahu, who led the heroic rescue operation in Entebbe. Benjamin Netanyahu himself is a former officer of an elite commando unit. There are 2 former IDF's chief of general staff in the government. The minister of defense, Mr. Barak was the 14th IDF's chief of general staff, and the minister for strategic affairs, Mr. Yaalon who was the 17th IDF's chief of general staff. There are 2 former major generals and 1 general, 1 former police deputy inspector general. 3 of the ministers are off springs of former major generals. The rest 6 ministers have clear connection to the military elite.

The issue of the Israeli National Security creates the most useful recruiting argument for supporting the government. Hence, the government maintains financially a large group of people, who belongs in the present and past, directly or indirectly to the national security forces (Shafir, and Peled, 2002 [19]; Etzioni-Halevy, 2000 [17]). This group serves as one of the biggest electoral group of citizens, and has powerful positions in the civil society and the government itself. This cohort, as I will further exemplify, for the financial benefits it gets, represent a critical mass in the Israeli civil society and in the government (Etzioni-Halevy, 2000) [17].

There are several ways to pay the military elite to support the government (Shafir and Peled, 2002 [19]; Etzioni-Halevy, 2000 [17]; Shapiro, 1996 [5]; Parry, 2005 [14]). One of the ways is to increase the National Security budget. The negotiations around how much to allocate to the military elite involve the argument that Israel has to prepare for "the next threat". This next threat argument is being used, by the military elite, in a form of blackmail. Since the military's duty is to provide security and defense for the homeland of Israel, an increasing fund is argued to bring more security and defense. The Israeli reality in the Middle East fuels the argument with examples. One time it is the Iranians who develop a nuclear threat, and another time it is the world terror that aims at destroying the country. While the threat is sophistically promoted, the support for the extended national security budget rises.

The National Security of Israel 2011 is almost 60 billion NIS out of total government budget of 270 billion NIS (according to the Budget Law 2011). The argument, in favor of allocating an extended uses fear as a main method. For example, claims such as the following are heard often: Who will train the soldiers for the next war? How will we fund the development of anti-missile projects? Who will defend the homeland if Iran and Syria will open a war? The public has no tools to evaluate such statements and can only accept and allow the increase in the budget. Only this week we heard that an addition budgetary fund of close to 1 billion NIS was approved to National Security purposes.

The mean number of years a government serves in Israel is less than 2 years out of the 4 they have been 
elected to serve (according to the Israel Democracy Institute). Government's stability, hence, is often unwavering, and has to base its support on a hard core who will lead on a fundamental ground. This fundamental ideology is the support to National Security issues (Etzioni-Halevy, 2000 [17]; Shafir and Peled, 2002 [19]). The power of the government increases by appointing the military elite members to key civil society positions. The penetration of former military personnel to the civil society, and the extended budget is meant mainly to increase the benefit of the elite members (Mills, 1956 [23]; Parry, 2005 [14]; Berelson, lazarfeld and McPhee, 1954 [24]).

\section{Conclusions}

In light of the above review, it seems that Israel is a unique case among the western democratic societies. Nevertheless, philanthropic activities are embedded in the Israeli and Jewish history as a superior Jewish value (Gidron, Bar and Katz, 2004) [25]. In order to be able to continue the enriching philanthropic activities in the country, a system of "checks and balances" for philanthropic activities has to be constituted. Instead of the process of a regulatory form, which has the ability to give birth to unwanted philanthropic activities, such as the New Israel Fund activities, a standard committee should take a dominant position in Israel. This regulatory committee should be composed of both government and philanthropic delegations that will decrease governmental regulations concerning philanthropic activities.

Despite the power of the government to regulate and decrease philanthropic activities in Israel, it should refrain from massively regulating. A massive regulation will decrease the involvement of philanthropies in Israel, and as a result it will decrease the benefit of the public as well. Instead, the government and the philanthropy should establish a buffering committee which standardizes the activities of philanthropy in Israel. Both government and philanthropy will benefit, as episodes such as the actions of the New Israel Fund will be narrowed down while acting in the public's best interest.

Foundations should refrain from disturbing the delicate political balance in Israel. Rather, they should concentrate on using philanthropic funds to promote social matters. Since philanthropy has the power to make a noticeable change in the social sphere, it should concentrate on doing so, rather than aiming at initiating a political change as well. At the same time, standards will enable wise and responsible investments, government and philanthropy cooperation, and effective allocation and use of funds. Furthermore, cooperation will diminish the mindset of the government that philanthropy is a problem.

\section{References}

[1] Almond, G. and Verba, S. (1963) The Civic Culture. Princeton University Press, Princeton.

[2] Koren, D. and Shapira, B. (1997) Coalition Politics in Israel. Zmora-Bitan Publishers, Tel-Aviv.

[3] Dahl, R.A. (1961) Who Governs? Yale University Press, New Haven.

[4] Harman, T. (1990) Elections, Elections Methods and Voting Behavior. Open University Press, Tel-Aviv.

[5] Shapiro, Y. (1996) Politicians as a Hegemonic Class: The Case of Israel. Sifriat Poalim, Tel Aviv.

[6] Dalton, R.J. (2008) Citizen Politics: Public Opinion and Political Parties in Advanced industrial Democracies. CQ Press, Washington DC.

[7] Wikipedia https://www.wikipedia.org/

[8] Guidestar http://www.guidestar.org.il/

[9] NIF http://NIF.org/

[10] Adalah Israel http://www.adalah.org/en/content/view/7189

[11] Maariv http://www.nrg.co.il/

[12] Nana http://www.nana10.co.il/

[13] News Channel 10. http://www.nana10.co.il/

[14] Parry, G. (2005) Political Elites. ECPR Press, Wivenhoe Park.

[15] Nicholls, A., Ed. (2008) Social Entrepreneurship: New Models of Sustainable Social Change. Oxford University Press, London.

[16] Lukes, S. (2005) Power: A Radical View. Macmillan Education Press, London.

[17] Etzioni-Halevy, E. (2000) The Divided People. Aryeh Nir Publishers Ltd., Tel-Aviv. 
[18] Shapiro, R.Y. and Jacobs, L. (2010) Simulating Representation: Elite Mobilization and Political Power in Health Care Reform. The Forum, $\mathbf{8}$.

[19] Shafir, G. and Peled, Y. (2002) Being Israeli: The Dynamics of Multiple Citizenship. Cambridge University Press, Cambridge. http://dx.doi.org/10.1017/CBO9781139164641

[20] Putman, R.D. (1976) The Comparative Study of Political Elites. Prentice-Hall, Inc., London.

[21] Gordon, C. (1980) Power/Knowledge: Selected Interviews and Other Writings 1972-1977. Pantheon Books, New York.

[22] Israel Ports http://www.israports.org.il/Pages/HomePage.aspx

[23] Shapiro, Y. (1984) An Elite without Successors: Generations of Political Leaders in Israel. Sifriat Poalim, Tel Aviv.

[24] Berelson, B., Lazarsfeld, P. and McPhee, W. (1954) Voting. University of Chicago Press, Chicago.

[25] Gidron, G., Bar, M. and Katz, H. (2004) The Israeli Third Sector: Between Welfare State and Civil Society. Plenum Publishers, New York. 